\title{
THE RUMP YUGOSLAVIA CONUNDRUM OF THE WEST: THE CHANCE OF \\ CONSOCIATIONAL DEMOCRACY IN THE POST-CONFLICT SOCIETIES
}

\author{
NAZÍF MANDACI
}

\begin{abstract}
The process of dismantling of Socialist Yugoslavia formed a litmus test for the Westerners' capacity to cope with the first and most serious crisis in Europe in the wake of the Cold War. The sequence of the events demonstrated that a monolithic strategy completely based on the recognition of the rights of people to secession had some debilitative outcomes and consequently, that the established borders should be preserved whatever it costed, in other words, even if they contained ethnic groups in hostilities. The West seems to have solved the problem in the latter's favor. However, the idea of protection of territorial integrity required generation of mutative political entities in the former Yugoslavia; i.e., in Bosnia, Kosovo and partly Macedonia whose chracteristics mostly recalling previously experienced consociational models of Cyprus, Lebanon and Nigeria. What makes the case problematic is the fact that the aforementioned political regimes failed, furthermore their failure considerably deluded the chance of their ethnic groups to co-exist in the future under the roof of the same state.
\end{abstract}

\section{KEYWORDS}

Yugoslavia, Internal/External Self-Determination, Power-Sharing, Consociationalism. 
The roots of nations are a controversial matter among the scholars. On the other side, the dispute as to who are eligible to have their own state and who are not is as conflagrant as the roots of the nations. It is generally assumed that desire for collective selfdetermination and consequently for an autonomous political organization, namely state, is encapsulated in human nature. However, this setting implies possibility of chaos in all sort of social organizations, or with the words of Buccheit who takes into account the international aspect of the issue, of the problem of 'indefinite divisibility', ${ }^{1}$ that is, eternal circle of secessions, be in state borders, or international system. Hence, the perilous content of the concept requires drawing a bold line between free individuals and free nations, another way of speaking, between internal and external selfdeterminations. Accordingly, individual self-determination regards to human beings' right to lead a life of dignity implying their freely and fully enjoyment of their natural rights; i.e., freedom to live, to express, to form associations and so forth. On the other side, concomitantly national self-determination is embodied in the will of a people and entails their right to have their most supreme political organization coincided with a demarcated area. In other words, the former signifies a philosophical approach giving priority to the wellbeing of individuals as the bearer of rights and responsibilities in a political community, whereas the latter locates the community, be an ethnic minority or a nation, at the centre of its investigation.

The former acquires its very meaning in a liberal understanding which prudently strips itself off the challenges stemming from differences on the ethnic, cultural, religious or linguistic bases. Having highly inspired from Locke, liberal view is suspicious for a state which organizes itself on the basis of legitimacy/accountability and which consequently respects and safeguards individual dignity, to instigate a process leading such undesirable indefinite divisibility. Accordingly, liberal view has a remedy. It harbors a notion of state which is strictly committed to the human rights and brings to the fore

\footnotetext{
${ }^{1}$ Michael Freeman, 'The Right to National Self-Determination: Ethical Problems and Practical Solutions', in Desmond M. Clarke and Charles Jones, (eds.), The Rights of Nations, New York: St.Martin's Press, 1999, p. 54.
} 
individual rights rather than ethnic, cultural rights ${ }^{2}$ and postulates that 'nothing be deemed as fundamental human good unless it is capable of being enjoyed as an enhancement of life by a human being as a distinct individual. ${ }^{3}$ However, liberal ideals are only the one side of the coin. The nature of ethnic conflict demonstrates that things are not as simple as they are assumed.

Although liberal and democratic traditions are distinct they have quite recently merged. ${ }^{4}$ As mentioned above, liberal theory chooses individual as the locus of investigation. On the other side, democratic theory gives priority to the will of the people and the issue of accountability. In this context, the issue of right of selfdetermination flows into another lake. Accordingly, democratic state is closely associated with nation, albeit there available varied approaches advocating that membership in an ideal democratic polity is irrelevant to, for instance, ethnocultural identities. At this point Gellner's opinion on the grounds that high culture comes to pervade whole society thanks to the quantitative qualifications of its followers, defines it and sustained by that polity, provides us with a vintage point. Modern society is inevitably democratic and national though a government which is adamantly loyal to the liberal ideals may avoid its turning into a conflict-ridden one, at least theoretically. However, functional imperatives of democratic polity do not necessarily bring similar benefits to the groups who speak a language other than that of majority in deed. For that reason, minority may be forced to make a choice between the three options: to bow to be assimilated; to come up with the demands regarding bilingualism, and if acutely needed, to redraw the boundaries of their own space in which they can run their economic-political activities in their own language. 'The nationalistic imperative is born's, the doors to the divisibility are open from now on. .

${ }^{2}$ Ibid., p. 53.

${ }^{3}$ Neil MacCormick, 'Liberalism, Nationalism and Self-Determination', in Desmond M. Clarke and Charles Jones, (eds.), The Rights of Nations, New York: St.Martin's Press, 1999, p. 68.

${ }^{4}$ Freeman, op. cit., p. 56.

${ }^{5}$ Charles Taylor, 'Nationalism and Modernity', in Robert McKim and Jeff McMahan, (eds.), The Morality of Nationalism, New York: Oxford University Press, 1997, p. 33. 
Kymlicka points out that the problem of the borders of community is as significant as the problem of accountability. Conventional political theory takes the borders of the political community as granted, supposes it as homogenous and put forth some parsimonious solutions as to how political power is to be distributed between the different levels. ${ }^{6}$ Although, forms of decentralization of political power occupies a significant space in theoretical debate on democratic regimes, in deed self-determination of particularly ethnic minorities has been adeptly avoided and established political center has continued to stand vigil against encroachments destining its dominant position. To be sure, there are some sharp distinctions between the recognition of the right of self-determination to an ethnic group and projects of decentralization in that the former means carving of a path that may lead to secession whilst the latter regards with further democratization, and obviously between their implications. Particularly in the societies which are sharply divided along ethnic lines empowerment of local governments may not be sufficient to soften ethnic tensions and drive them to seek more radical solutions, the worst of which is separatist movement.

Some students of political theory underlined that even in deeply divided societies democratic institutions have chance to survive and secessionism can be ruled out. Lustick underlines that the phrase of 'deeply divided' has varied meanings altering from 'plural', to 'communally divided'. Accordingly, a society is deeply divided should 'ascriptive ties generate an antagonistic segmentation of society, based on terminal identities with high political salience, sustained over a substantial period of time and a wide variety of issues. ${ }^{7}$ Consequently, in societies ascriptive or primordial ties give its color to the politics, the willingness on the part of national minorities to redraw the political borders to enhance their political representation heightens. According to Kymlicka, liberalist approach prefers to remain silent on the question of how to deal with minority

${ }^{6}$ Will Kymlicka, 'Introductions', in Will Kymlicka, (ed.), The Rights of Minority Cultures, New York: Oxford University Press, 1997, p. 1-27.

${ }^{7}$ Ian Lustick, 'Stability in Deeply Divided Societies: Consociationalism versus Control,' in John Hutchinson and A. D. Smith, Nationalism: Critical Concepts in Political Science, Vol. 5, New York: Routledge, 2000, p. 1743. 
nationalisms, ${ }^{8}$ especially after the mentioned threshold was overrun; in other words, after nationalistic imperative was born. Lijphart contends that consociationalism can enhance the chance of peaceful coexistence of ethnic communities in a democratic polity. However, consociationalism is entirely relied upon 'cooperative efforts of community elite to counteract the centrifugal tendencies of cultural fragmentation.' Hence, consociational model requires firm elite control over respective communities, elite commitment to political platform on which inter-elite, or essentially inter-communal bargain is conducted. ${ }^{9}$ Consequently, consociationalism allows generation of public policy on the basis of communal interests rather than individual ones.

However, the lessons which have been extracted from the former experiences with consociational models in conflict-ridden geographies like Cyprus, Lebanon and Nigeria, ${ }^{10}$ have unfolded that elite monopoly ought to be complemented with the existence some other conditions. First of all, consociational democracy requires introduction of some political procedures or if needed, establishment of some institutions. Adoption of constitutional veto is one of those procedures. Thanks to the constitutional veto or ethnic veto, national minorities acquire the power to blockade decision-making process, should they are not in their favor. Consociational model also necessitates impartial (just-equal) representation of the communities. Here impartiality connotes a standard that is higher than proportionality thereby giving to the political system its communal-

${ }^{8}$ Will Kymlicka, 'Minority Nationalism within Liberal Democracies', in Desmond M. Clarke and Charles Jones, (eds.), The Rights of Nations, New York: St.Martin's Press, 1999, p. 100.

${ }^{9}$ Lustick, op. cit., p. 1746.

${ }^{10}$ One should remind that Lijphart mostly concentrated on consociational regimes in Canada, pre-civil war Lebanon and the smaller European democracies (Austria, the Netherlands, Belgium and Switzerland). See, Arendt Ljiphart, Democracies of Majoritarian and Consensus Government in Twenty-One Countries, New Haven and London: Yale University Press, 1984; and, Arendt Ljiphart, The Politics of Accomodation, Pluralism and Democracy in Netherlands, Berkeley, Los Angeles, London: University of California Press, 1975. 
interest-based character. ${ }^{11}$ In parallel Lijphart underlines that delegation of decision making can be distributed as much as possible between communities. He points out another basic principle; namely 'grand coalition' which will consist of community leaders as partners. In a parliamentarian system it may take the form of a grand coalition cabinet and in a presidential system, the post can be embodied in a council that will include of the representatives of the communities. Those principal principles can be supplemented by some other secondary principles like 'proportionality', implying the determination of contingents in public service and the allocation of public funds between the segments. Lastly, the principle of ethnic veto is the ultimate weapon in the hands of minority since it provides it with essential protection against the tyranny of majority on the vital issues. $^{12}$

\section{The Dilemma of the West: Territorial Integrity or Self- Determination}

The political developments following the collapse of the socialist regimes in Europe demonstrated us how the right of selfdetermination has been conceptualized as subject to foreign policy priorities of the triumphant states of the Western block. In the heyday of the anti-socialism the nations who had been supposed to be under the yoke of the totalitarian regimes of Yugoslavia were encouraged to run after their fair right of self-determination. A survey conducted in the beginning of the 1990s by the European Barometer on the

\footnotetext{
${ }^{11}$ Those issues gained highly speculative character in Macedonian academic echelons particularly on the eve of the ratification of constitutional amendments in the Macedonian National Assembly. The characteristics of consociational regime were comprehensively singled out by professor of law Ivanov who intended to unveil the constitutional changes in reality generated political structure recalling consociationalism. See Gjorgje İvanov, Draft Amendments to the Constitution of the Republic of Macedonia: Supplement to Public Debate, Panel held to the honour of 50. year of the University of Ss. Cyril and Methodius Faculty of Law, Skopje: Cyril and Methodius University Press, 31 July 2001, p. 45-51.

${ }^{12}$ Arendt Ljiphard, 'Self-determination versus Pre-determination of Ethnic Minorities in Power Sharing Systems' in Will Kymlicka (ed.) The Rights of Minority Cultures, Oxford: Oxford University Press, 1997, pp. 275-287.
} 
expectations of the Europeans for the future of the peoples of Yugoslavia indicated that 70 percent of the attendants supported the right of self-determination of the involved nations. ${ }^{13}$ Even demagogues like Milosevic were applauded wholeheartedly without seeking their political career as the heroes of democratic cause. Of course, that was as prudent as sentimental stance since European endorsement accelerated the dismemberment of the socialist block in a short period. ${ }^{14}$ However, the shedding of blood in Bosnia due to the Croatian and Serbian secessionisms and aggregation of immigrants who fled for saving their lives before the doors of Europe brought the Europeans to their true sense and urged them to reevaluate their staunch support to the right of self-determination of the peoples under the light of the harsh realities of status quo.

The lesson extracted from the Yugoslav case forced the Western capitals to elaborate the fact that self-determination issue inherently harbored the problem of territory and irredentism. Consequently, Westerners started to handle the problem on the basis of the implementation of liberal-democratic ideals thereby escaping their post-Cold War dilemma between self-determination and preservation of the territorial integrity of the prevailed nations. This new political stand implied that the Westerners should remain equidistant to the peoples struggling for their sovereignty and to the established political centers which were vigilant against any attempt jeopardizing its jurisdiction in their own demarcated areas. However, the West tried to solve the riddle by ruling out entirely external selfdetermination and by spurring the fledgling democratic regimes of the region to adopt democratic institutions on the basis of internal selfdetermination, of course along with liberal economic practices. The Badinter Committee of 1992 was designed for this aim.

The committee conditioned diplomatic recognition of the former Yugoslav and Soviet republics on the existence of sufficient level of democracy, human rights, protection of minorities, progress

\footnotetext{
${ }^{13}$ Leonard J. Cohen, Broken Bonds: The Disintegration of Yugoslavia, Boulder, San Francisco and Oxford, 1993, s. 50.

${ }^{14}$ Raju G.C. Thomas, "Nations, States and War," in Raju G.C. Thomas and H. Richard Friman, (eds.), The South Slav Conflict, History, Religion, Ethnicity and Nationalism, New York and London: 1996, pp. 204-205.
} 
towards a market economy, commitment to peaceful resolution of disputes and guarantees relating lack of territorial aspirations over territories of the neighboring nations. ${ }^{15}$ Furthermore, the committee's resolutions reflected the concerns of the West on the grounds that debate on self-determination might lead to a zero-sum-game between the ruling majorities and ruled minorities. For instance, the committee stipulated on its resolution on the Serbs in Croatia, dated February 11, 1992 that national minorities could enjoy their rights of selfdetermination only within the boundaries of the hosting state. ${ }^{16}$ Hence, the West tailored itself a role of prompter whispering the ears of the nomenclature what to do when they encountered with defying nationalist causes from within. However, that was not sufficient to plant the seeds of democracy in the region and crisis in Bosnia escalated into so uncontrollable levels as to require an active Western intervention.

As it turned out, the strategy of the West in the Balkans underwent a metamorphosis and turned it into an active political agent for regional stability. In the beginning of the Bosnia crisis critiques of a possible US intervention had become vocal. Those who oppose the US administration to plunge into the Balkan quagmire underlined the fact that US had no vital interest in the region since no Balkanic power posed threat to the security of Europe. ${ }^{17}$ Furthermore, the same clique advocated that the European Union should be given a chance to prove its eligibility to cope with a problem in its backyard. ${ }^{18}$ Yet, naïve political cooperation in foreign affairs inhibited an energetic European response to the crisis and only the

${ }^{15}$ Loring M. Danforth, The Macedonian Conflict, Ethnic Nationalism in a Transnational World, Princeton: Princeton University Press, 1995, p. 148.

${ }^{16}$ Tatjana Petrusevska, Draft Amendments to the Constitution of the Republic of Macedonia: Supplement to the Public Debate, Yayınlanmış Bildiri, Panel at Teachers' College of the Faculty of Law of the Ss. Cyril and Methodius University’, Skopje, 21 July 2001, s. 45-51.

${ }^{17}$ Radovan Vukadinovic, 'American Policy in the South East Europe', Copenhagen Peace Research Institute, Foreign Policy Paper, October 2002, 15 December 2004, http://www.ciaonet.org/wps/sites/copri.html.

${ }^{18}$ Ted Glen Carpenter, 'Foreign Policy Masochism: The Campaign for US Intervention in Yugoslavia', The Cato Institute, Foreign Policy Briefing No: 19, July 1992, http://www.ciaonet.org/contrib.html\#cat; 15 December 2004. 
war scenes reflected from the TV screens that managed to instigate a public opinion pressure on the Western capitals generated an active Western engagement with the conflict at last. In the case of Kosovo, the Western powers seemed to have extrapolated some lessons from their first engagement and did not permit any serious delay ${ }^{19}$ this time that might have destabilized the Southeastern Europe while Milosevic regime put into operation his notorious Operation Horse Shoe ${ }^{20}$ overtly aiming at de-Albanizing the province. As for Macedonia, it was another story.

The West engaged in the post-Yugoslavia politics several times since the beginning of the dismemberment process. Bosnia was the most tragical one in that literally a limited air campaign convinced the Bosnian Serbs to come to terms of the game and shown the world that diplomatic babble had only served to further bloodshed in the region. Kosovo crisis also required an active Western intervention on behalf of humanitarian values probably for the flow of immigrants inside Macedonian territory would have exasperated the ongoing inter-ethnic conflict between the two hostile ethnic communities in the fledgling Macedonian Republic thereby even undermining the Eastern Mediterranean pillars of the triumphant NATO. The crisis in Macedonia was the last stage of the Western intervention, an offshoot

${ }^{19}$ Christopher Layne, 'Blunder in the Balkans: The Clinton Administration's Bungled War against Serbia', Policy Analysis, No: 345, May 1999. 15 December 2004, http://www.ciaonet.org/contrib.html\#lac. However, Layne pointed out that rush of the US administration to pursue a punishment policy against the Serbs did not culminate in expected results and it constituted the basic reason of the Serbian recalcitrance not to partake in the political reformation in Kosovo under UN protectorate.

${ }^{20}$ For many sources, the existence of an Operation Horseshoe is speculative. But whatever design behind the campaigns of the Yugoslav forces, it seemed that the Serbs attempted to take the revenge of the NATO attacks over the non-Christian citizens of Kosovo. The results were so debilitative for all communities of the province. During the NATO campaign approximately 860.000 people were forced to seek shelter outside of Kosovo. In addition about 560.000 were internally displaced. After the defeat of the Yugoslav army here, exhumations conducted under the tutelage of ICTY found out 2.205 bodies in 345 mass graves. It was also reported that around 2.150 civilians were missing, most of whom was estimated to be killed. 
of the Kosovo politics since the armed confrontation between the Albanian ONA and the Macedonian forces would have inflicted a huge damage upon the peace-keeping operations chain stretching from Bosnia inside the Macedonia proper. ${ }^{21}$ The West also extended its help to rebellious Podgorica which was eager to separate its way with notorious Milosevic regime in Belgrade; at least until the Yugoslav army withdrawn from its positions in Kosovo. ${ }^{22}$ Besides, Croatia was forced to sign and implement an agreement creating an interim administration (UNTAES) regarding the protection of the Serbian population in Eastern Slavonia, Baranja and Western Sirmium in $1995 .{ }^{23}$ However, the last two were not included in the political reforms scheme of the West in the region

With the settlement of the conflicts, the West found an unprecedented opportunity to turn those geographies into political laboratories in which it could comfortably install, or uninstall if needed, a set of political institutions which would be charged with introducing and implementing liberal-democratic ideals in communities divided along ethnic lines. Actually, it has been witnessed so far that the West has resolved to solve the problems of the post-conflict period entailing representation, economic and social integration with the help of political restructuring programs which include many elements considerably overlapped with the characteristics of consociational regimes. In Bosnia and Kosovo those political restructuring programs have been placed under firm cooptation of foreign governors whereas in Macedonia political

${ }^{21}$ Mario Zucconi, 'The External Factor: The Macedonian State's Security Deficit and the International Community', in Minority Politics in Southeast Europe, Roma: The Ethnobarometer Working Papers Series, Graphorama, 2002, s. 87. The clashes between the Albanian ONA and the Macedonian security forces developed in the vicinity of the base of KFOR-Rear, a task force formed to support the KFOR in Kosovo.

${ }^{22}$ Nazif Mandac1, 'Is Montenegro the Next' Perceptions, Vol. VI, No:4, December 2001-February 2002, pp. 79-96.

${ }^{23}$ Croatia took over the control of the region in the beginning of 1995 . See Gojko Vuckovic, 'Promoting Peace and Stability in the Aftermath of the Balkan Wars: Comparative Assessment of the Democratization and Institutional Building Processes in Croatia, Bosnia and Herzegovina and FR Yugoslavia', Center For International Studies, 15 December 2004, http://www.ciaonet.org/wps/vug01/\#txt23. 
reforms have been scrutinized by a corpus of foreign diplomats supported by subsequent task forces. ${ }^{24}$ However, it seems that the resolution of the West to observe a fragile equilibrium between territorial integrity and self-determination right of the composing ethnic communities has procured mutative entities, in Bosnia a state composed of a Croat-Muslim federation along with a Republika Srpska; in Kosovo a province which would reportedly be less than federal yet beyond autonomous entity; in Macedonia a disputable unitary state.

\section{Search for Political Remedy and Power-Sharing Democracies in the Conflict-Ridden Regions}

In Bosnia the West pressed for an integrated Bosnia whilst recognizing its de facto division between the hostile peoples. According to Carpenter, the Dayton Agreement was 'a blueprint for disaster' simply because the Serbs would have never given up their aspirations of integration with Serbia, and the coalition between the

${ }^{24}$ NATO General Secretary Javier Solana was one of the distinguished mediators between the clashing parties in Western Macedonia. Having obtained the consent of the protagonists and in accordance with the threestage plan of President Trajkovski, NATO started 'Operation Essential Harvest' designed for the disarmament of the ONA. Following the collection of the weapons, the Macedonian National Assembly pushed a cluster of constitutional amendments introducing or buttressing political institutions, to the chagrin of the Macedonian minority, connoting a powersharing regime. During the feverish debacle in the parliament, stability in the region was ensured by a new task force under 'Operation Amber Fox.' The task force was also charged with the protection of the foreign envoys who had been to the region due to inspect implementation of post-conflict arrangements and mandated with the role of arbitrator between the parties until the Macedonian state gained the control of the conflict-ridden region. The Amber Fox was succeeded by a new force, 'Concordia' under the command of the EU by the fall of 2002 and the new task force took over the former's responsibilities of inspecting, arbitrating in the process of normalization in the Western Macedonia. 
Croats and Muslims was 'a matter of expediency.'25 Actually, the agreement contained political, economic commitments of the international community to assist the formerly warring parties to coexist under the roof of single multiethnic political entity. It was expected that with the assistance of the foreigners and right sense of the political leaders who would strip themselves off ethnic colors and in stead, act on behalf of everyone, the main well-springs of the conflict relating economic backwardness, ethnic, religious, cultural differences would have been drained. To be sure, arms control, imprisonment of indicted war criminals, return of the refugees, restoration of freedom of movement across the country should be given priority for the maturation of the conditions for inter-ethnic cooperation.

It was supposed that the war, as in the cases of Slovenia and Croatia, was resulted from aggressive policies of Belgrade, and from the nomenclature that concerned with retaining political power and triggered ethnic hostilities. Accordingly, the three communities were unwilling participants of the war and the victims of their warmongering leaders. ${ }^{26}$ Hence, a more sensible distribution of power under a firm suzerainty of a foreign governor, only for now, working with a new group of amiable and committed community leaders, the possibility for a multicultural, democratic political community was still promising. Nevertheless, only after five years, the academic echelons were preoccupied with finding out the reason why the international community failed here and policy makers were recommended that they recognize that 'Bosnia was not a Western state and that the country's bewildering social, economic, political structures could not be understood by viewing them through a Western prism.' ${ }^{27}$ As it turned out, it appeared that memoirs of the

${ }^{25}$ Ted Glen Carpenter, 'Holbrooke Horror: The US Plan for Bosnia', The Cato Institute, Foreign Policy Briefing, No: 37, October 1995, 15 December 2004, http://www.ciaonet.org/contrib.html\#cat.

${ }^{26}$ Susan L. Woodward, 'Intervention in Civil Wars: Bosnia and Herzegovina', Institute of War and Peace Studies, Foreign Policy Draft Paper, $\quad$ February $1997, \quad$ 15.12.2004, http://www.ciaonet.org/contrib.html\#wos.

${ }^{27}$ Mark Edmond Clarke, 'Ideas on Bosnia for the Bush Administration', Columbia International Affairs Online, 15 December 2004, http://www.ciaonet.org/contrib.html\#clm. 
bloodshed would hardly erased, the indicted criminals who once had been their emotional leaders and symbols of authority and allegedly defended solely their respective ethnic causes could not be captured (!), the distance between the ethnic communities, particularly Republika Srpska and the rest $\mathrm{t}^{28}$ as well as the ardently nationalists' or nomenclature's position in political pyramid of communities remained intact

In Kosovo, before the outbreak of the conflict the international community was called for putting efficient measures into operation to avoid escalation of ethnic hatred between the Albanian majority and the Serbian minority. Those were singled out as confidence-building measures, political dialogue and negotiations with the protagonists; immediate and full restoration of civil and human rights of the Kosovo Albanians; appointment of a high-level special envoy to deal with the implementation of the involved measures, extending economic aid and lastly buttressing of civil society, democratic institutions in both Serbia and the Kosovo proper. ${ }^{29}$ Yet ongoing atrocities and failure of the Rambouillet process accelerated a courageous decision of military intervention. ${ }^{30}$ Upon the escalation of the concerns on the grounds that now the Albanian majority of the province faced with a deliberate ethnic cleansing campaign, NATO intervened on 24 March 1999. Upon the military demarche, Belgrade had to accept the joint plan of the G-8 countries (USA, Britain, France, Russia, Germany, Japan, Canada and Italy) and Yugoslav forces withdrawn from Kosovo.

On 10 June 1999 with United Nations Security Council Resolution 1244 the United Nations Interim Mission in Kosovo (UNMIK) was tasked with coordinating the political reorganization of the province on the basis of self-determination and providing and

${ }^{28}$ Wolfang Biermann and Martin Vadset, 'Lessons Learned From Former Yugoslavia', Copenhagen Peace Institute, Report of Conference held in Copenhagen, Denmark, 12-14 April 1996, 15 December 2004, http://www.ciaonet.org/contrib.html\#biw.

${ }^{29}$ Carnegie Endowment for International Peace, 'Kosovo: From Crisis to a Permanent Solution', November 1 1997, 15 December 2004, http://www.ciaonet.org/wps/sites/ceip.html.

${ }^{30}$ The Independent International Commission on Kosovo, Kosovo Report, October 2000, p. 76, http://www.kosovocommission.org/. 
protecting minorities. Although, the Resolution 1244 reiterated and confirmed the sovereignty of Yugoslavia over the province, its administration was left provisionally to the UN. By 15 May 2001, the date when the provisional administration and the communities in Kosovo reached an agreement for the main framework for the selfadministration of the province, UNMIK had enacted many regulations organizing the political, social, economic and cultural life in Kosovo. This new framework or so-called 'Constitutional Framework' laid the foundations of the new political and administrative structure in Kosovo under the tutelage of the Special Representative of the Secretary General of the United States (SRSG).

The UNMIK Regulation 2001/9 on the Constitutional Framework for Provisional Self Government ${ }^{31}$ constituted the most important step in the process of establishing a meaningful selfgovernment in Kosovo under the tutelage of international community. The parties in Kosovo had reached an important phase of this process that had started with the establishment of Joint Interim Administration Structures (JIAS) allowing them to take the responsibility gradually for the administration of Kosovo. In pursuant with the UN Security Council Resolution 1244, UNMIK shown its commitment to the plans for transferring these responsibilities to the Provisional Institutions of Self-Government that would assume the function of ensuring conditions for peaceful and normal life for all inhabitants of Kosovo. In addition, these provisional institutions were expected to determine the future status of the province through a proper political process that would be based on the free will of its people. It was underlined that a parliamentarian democracy would enhance democratic governance and respect to rule of law, whilst adoption of market economy would promote economic prosperity and welfare of the people of Kosovo.

However, this parliamentarian democracy would continue to be under the firm control of the SRSG. The SRSG would retain the authority to intervene in due to protecting the rights of communities and their members. Accordingly, the powers and responsibilities of the Provisional Institutions of Self-Government would not include

\footnotetext{
${ }^{31}$ The UNMIK Regulation 2001/9 Constitutional Framework for Provisional Self-Government, 15 May 2001.
} 
certain reserved power and responsibilities remained exclusively in the hands of the SRSG. The SRSG would posses the right to dissolve the assembly and calling for new election in cases of violation of the rights of communities by the Provisional Institutions. He had the right to say the ultimate word on the local municipal administrations' acts, budgets of and appointments to governmental agencies. Kosovo was another typical sample of power-sharing democracy strengthened with political procedures designed for preventing abuse of the rights of minorities, particularly Serbs by the majority Albanians. For instance, in 120-seat Assembly of Kosovo, 20 seat-asides were allotted for the communities who declared themselves as nonAlbanian. Of 20 seats, 10 would be owned by the Serbian minority and they would be represented in the Presidential Assembly by a Serbian deputy. As for the seats in the assembly committees, they would be distributed proportionally on the ethnic basis too. In order to protect the communal rights of the minorities an innovative political institution so-called 'Panel' that would be mandated by the SRSG to arbitrate between the involved parties was introduced. Yet, the SRSG would retain the right to say the ultimate word on the matter.

In Kosovo, the West encountered with the same problem. Due to the nature of a power-sharing system, the political institutions could be operated healthily only if the political leaders managed to overwhelm their fervent nationalist causes, amiably adopted those political institutions as their own and steer their own flock accordingly. However, 'the nationalistic imperative' had already flourished on these soils in the beginning of the 1990's due to repressive policies of Milosevic regime as well as the West's turning a blind eye to the political demands of the Albanian majority as the Joint Action Program for Bosnia in May $1993^{32}$ and later the Dayton Agreement of 1995 confirmed. ${ }^{33}$ Owing to the Serbian recalcitrance, the Albanians had already created a parallel state administration in the province which functioned in several fields of classic public services like education and health under the shadow government of

${ }^{32}$ Dimitros Triantaphyllou, 'Kosovo Today, Is There No Way out of the Deadlock', European Security, Vol. 5, No. 2 (Summer 1996).

${ }^{33}$ David L. Phillips, "Comprehensive Peace in the Balkans: The Kosovo Question,” Human Rights Quarterly Vol. 18, No. 4 (November 1996) 
Ibrahim Rugova and boycotted the Belgrade-administered institutions. ${ }^{34}$

Nevertheless, after NATO intervened and UNMIK was commissioned, it was the turn of the Serbs. Despite the oust of the Milosevic regime and appearance of political clique in Belgrade which favored a swift solution in Kosovo as soon as possible -of course in return some concessions favoring the Serbs in Bosnia- and political, economic reforms that would accelerate the process of adherence to the EU, the Serbian minority of Kosovo remained recalcitrant not to integrate in post-conflict Kosovo political structures. After diplomatic demarches both from the West and Belgrade the Kosovar Serbs eventually acquiesced to participate in the first general elections under the terms of the new constitutional framework. Yet, in the province no multicultural democracy even in Kosovar mode, let aside Western one, is in prospect unless ardent nationalists ceased to constitute outstanding political alternatives within their communities respectively, and orthodox clergy on both sides, yet particularly on the Serbian side, relinquished to give the matter spiritual colors. Ironically, some circles defended this political uncertainty in Kosovo as of constructive nature ${ }^{35}$ that would force the protagonists to make a choice between chaos and order. Yet question is relevant to what if the two communities prefer order in their own political spaces in stead of chaos of coexistence.

The conflict in Macedonia escalated up to the level of armed confrontation was considered by some observers as the prolongation of the crises experienced in Kosovo and the southern Serbia, Presevo Valley. ${ }^{36}$ Ironically, the doomsday scenarios that AlbanianMacedonian division might have triggered old Serbian, Bulgarian and Greek aspirations over Macedonia thereby led to the collapse of the eastern Mediterranean pillar of NATO by dragging Greece and

${ }^{34}$ Ben Lombardi, 'Kosovo: Introduction to Yet Another Balkan Problem', European Security, Vol. 5, No.2, (Summer 1996).

${ }^{35}$ Justin L.C. Eldridge, 'Kosovo: Land of Uncertainty', European Security, Vol. 10, No. 2. (Summer 2001), p. 38.

${ }^{36}$ Mario Zucconi, 'The External Factor: The Macedonian State's Security Deficit and the International Community', Minority Politics in Southeast Europe, Roma: The Ethnobarometer Working Papers Series, Graphorama, 2002, p. 87. 
Turkey to a new conflict, all had long gone out of date. Bulgaria was tamed through offer of full membership in EU. Serbia was trying to prove to the West that it favored revision through peaceful means while Greece had long been aware of the possible implications of the instability in its north, furthermore it assumed the role of a Western agent of regional stability. However, Macedonia was the last station at which the train of political reformation ought to arrive to complete the grandiose project of stability in the Balkan Peninsula. Particularly, debates on the transfer of the commandment of Amber Fox to the Europeans unfolded that Westerners were deeply concerned with the preservation of fragile institutional integration between SFOR in Bosnia, KFOR in Kosovo and KFOR-Rear in the Macedonia proper. ${ }^{37}$ On the other side, Albanian leaders appreciated the internationalization of their problems, and welcomed a possible Western intervention in the name of buttressing democracy in Macedonia. Yet, Macedonian leaders showed their reluctance to cooperate in varied platforms right for this reason.

The constitutional amendments in compliance with the accord signed by the parties to the conflict and the Western plenipotentiaries in Skopje provided the Albanian community with some check-valves; i.e., an efficient ethnic veto mechanism, some intermediary political institutions, devolution of power; against majority supremacy of classical democracy. Western mediation succeeded to bring even miraculous into being by persuading guerilla leaders to drop from their guerilla strongholds on the hills into parliament seats, and the Macedonians to recognize their political immunity. Furthermore, the old Albanian political clique who had long been accused of embroiling in corruption and their patronage networks seemed to have evaporated overnight. The West also accepted to shoulder the financial burden of reconstruction of economy and the damaged infrastructure as well as political reformation. Consequently, an all fledged consensus democracy was now in prospect. However, as the last referendum on the constitutional amendments within the

${ }^{37}$ Caroline Earle, 'EU Contributions to Peace Operations: Development of an European Rapid Reaction Force and Ciyilian Capacity', Peace Operations Fact Sheet Series, Washington: The Henry L. Stimson Center, May 2002, p. 1-3. 
framework of the Ohrid Agreement ${ }^{38}$ indicated something has gone wrong, the peace is still fragile, and tensions are waiting for a proper time, a change of mode to surface. Obviously, the most important factor that has so far cushioned the blows of ethnic hostilities boiling underneath has been prospect for a possible membership in EU. Even the leaders of the Albanian ONA had declared that they had seen the constitutional amendments as the first step to fulfill one of the basic requirements of EU membership. ${ }^{39}$ Yet, the Macedonian side believes that the amendments were dictated by the West blinking the outlawed ONA. Thus, in the absentee of foreign support it is still uncertain that the Macedonian democracy based on power sharing structures will remain standing.

\section{The Chance of Power-Sharing Model to Survive}

It follows that the Western concerns to observe the fragile balance between territorial integrity and the right of selfdetermination necessitated a deliberate response to the political realities of the region. However, as mentioned above, Western engagement with the protracted conflicts between the ethnic groups ironically cultivated mutative political entities. Furthermore, it seems that in those political laboratories the selected political embryos are embolied in an alien physical entity without assuring the expected outcomes. In reality, consociational democracies which are offered as the solution to the problem of political integration require some minimum societal conditions, or with the words of Ivanov, the

${ }^{38}$ The Ohrid Agreement was signed by the leaders of the Macedonian and Albanian parties which had seats in the parliament. The nationalist flank of the Macedonian leaders pressed for the holding of a referendum for the amendments. However, they failed and the involved amendments were ratified in the National Assembly and put into force. Yet, nationalists, particularly VMRO did not give in and maintained its determination to the hilt and succeeded in the end. Yet, unfortunate for the VMRO, the turnout as well as the number of those who opposed constitutional amendments remained considerably low.

${ }^{39}$ Iso Rusi, 'The Political Realignment of Macedonia's Albanians', AIM, 19

January 2002, 15 December 2004,
http://www.aimpress.org/dyn/trae/archive/data/200201/20119-005-traesko.htm. 
absentee of 'some cracks the community can not come across. 40 These can be singled out firstly as the existence of overlapping identities whereby need to ethnic belonging loses its priority for individuals and consequently cross-cutting cleavages denoting that ethnicity does not play the pivotal role in the determination of the courses for self-benefit. ${ }^{41}$ For instance, class solidarity may strip the process of public policy formulation off its ethnic jacket. Second one is the existence of a multi-level balance of power between the segments. Bosnia is the typical example to such a segmentation of autonomy, yet, this political posturing seems to have served so far to polarization rather than integration. Thirdly, a looming external danger may encourage the communities to embark a broad political cooperation. However, in the three cases external threat has not been observed through the same lenses.

The most significant yet missing ingredient for the Western inculcated power-sharing models in the region is 'the tradition of political commodity and tolerance' 42 between the involved communities. Since the ideals of liberalism that badly need autonomous individuals, thinking, acting, bargaining rationally independent from ascriptive ties were highly utopian for the region, the Western preference to create political entities in which only intercommunal trade-off would determine the public policy, seemed reasonable. However, social relations between the communities of the region have always been characterized by astonishing and constant transition from superior to inferior, or vice-versa. For example, once overlords within the old millet system of the Ottoman Empire, Muslims and Albanians lost their superior status in the Kingdom of the Serbs, Croats and Slovenes and later the socialist Yugoslav regime could not meet exactly their demands of restoration until the 1970s. They lost again what they had obtained in the beginning of the 1990s and regained by the end of the millennium. On the other side, consociationalism is literally based on sound consensus between the elite that obtained the full support of their respective communities, to

\footnotetext{
${ }^{40}$ Ivanov, op.cit., p. 49.

${ }^{41}$ Larry Diamond and Marc F Plattner, 'Introduction', in Larry Diamond and Marc F. Plattner, (eds.), Nationalism, Ethnic Conflict and Democracy, Baltimore: Johns Hopkins University Press, 1994, pp. 9-30.

${ }^{42}$ Ivanov, op.cit., p. 50.
} 
the survival of established political structure. However, in reality leaders have displayed in varied platforms their discontent about the political structures and revisionist ideals are expressed not only by the losers but also by the winners. Besides, one should remind that the elite cooperation in the region has been reluctant and provided thanks to the prudent carrot and stick policies by the external forces.

Then, what are the other political formulas if the current one does not work out properly? It seems, there available no alternative other than permitting those communities to do their own way. Yet, what about its implications? Of course, it implies another looming chaos in the region; violence, diplomatic babble for the share of soil, ethnic pockets, state assets and so forth. As reiterated above, a liberal democracy of citizens can hardly be created in those societies and split between the communities forces us to endure difficult powersharing models despite all its flaws. If there is no secession in the end, power-sharing model can not be taken to be a tentative remedy or a transition formula as if those societies march off to a liberal democratic future. What differs post-Yugoslav consociationalisms from their counterparts in Holland, Austria or Switzerland is the fact that in Europe democratic traditions had flourished along with sectarian or ethnic divisions on the same soil and during a permanent process of mostly peaceful trade off. In post-conflict Yugoslavia, consociationalism has been something injected from without into the societies having suffered the trauma of the recent turmoil; and in the name of preservation of status quo. Thus, power-sharing can survive at least as long as its Western clients continue to see it in their own favor.

Of course, this setting implies that the West should proceed to its policy of protectorates in Bosnia and Kosovo, and its diplomatic acrobatics in Macedonia. The Special Representatives should retain their cooptation mandate in order to blockade legislatives jeopardizing vital interests of national minorities. Foreign troops should monitor the process of normalization of social life in terms of freedom of movement, return of the refugees and so forth, shuttle diplomacy should be run to recover the gaps between the codified and its implementation. Probably, generation of a secure environment around the hostile societies may supplement diplomatic and military measures. In reality, integration of the neighboring nations to the Euro-Atlantic structures, their association with the Western- 
sponsored regional organizations designed for economic, cultural even military cooperation, and a credible prospect for full membership in the European Union, all have managed by and large to erode irredentism that had been haunting over the southeastern Europe as a whole in the wake of the Cold War. Particularly the last one poses as a handle or magical stick or carrot or whatever, the West has. It follows that accession to EU is considered as the golden apple by a significant part of the regional political elite. Nevertheless, success of EU prospect in Macedonia may be an exemption. The fate of Serbian Prime Minister Djindic who allegedly dared to assess a possible trade off between Kosovo and EU membership overshadows the Macedonian case. In a region where epic stories of heroes, martyrs and traitors delimit the social imagination of the world the inculcation of inherently inclusive political models heralds a tedious enterprise in deed. The West has tended to call the region 'southeastern Europe' instead of pejorative Balkans whereby it signaled its willingness to see the nations of the region as the part of democratic Europe. It is now the turn of the Balkanic peoples to take step forward; they have no alternative but a historical opportunity, albeit it has been dictated from without. 